\title{
Game Analysis and System Construction of College Students' Employment Service System of Socialization - Based on Multi-Objective Decision Making Perspective
}

\author{
Min Duan and Yongbo Lv*
}

School of Traffic and Transportation, Beijing Jiaotong University, Beijing 100044, P.R. China

\begin{abstract}
There are several goals divided between governments, undergraduate employment service agencies, and employment intermediary organizations of social college students. They are directly related to each other, and are the key to achieve the multi-objective utility. In this paper, the game equilibrium solution has been analyzed correspondingly, and finally put forward to construct the social service system for undergraduate employment service system. The system is based on four strategies of strengthening the college students employment service system include social concept, scientific orientation, further tapping social resources, and establishing service system.
\end{abstract}

Keywords: Game analysis, Multi-objective decision, Social service system, Undergraduate employment.

\section{INTRODUCTION}

Achieving a systematical, professional, and social employment service system has been proposed on National Reemployment Work Conference, which is an important strategic thought put forward based on the development trend of our country's current employment service system. Undergraduate employment service system is of great importance in the whole employment service system. We should seriously probe into the concrete features of undergraduate employment service system of socialization, find out the rules of undergraduate employment service system of socialization, correctly understand it, and reasonably deal with practical problems faced by undergraduate employment service system of socialization. All these issues have both theoretical and practical significance for better employment of China's college students.

\section{MULTI-OBJECTIVE UTILITY MODEL OF UN- DERGRADUATE SOCIAL SERVICE SYSTEM}

The employment service system of socialization adjusts the system and mechanism arrangement of undergraduate employment services. In this way, it has transformed public employment service function dominated by government, into a comprehensive undergraduate employment service system integrating public employment service function dominated by government and involved by related enterprises, associations, cooperative organizations and schools, with operational employment service function created by other intermediary organizations and social strengths.

Undergraduate employment social service system specifically includes government undergraduate employment

*Address correspondence to this author at the School of Traffic and Transportation, Beijing Jiaotong University, Beijing 100044, China; Tel: +86 13938500906; E-mail: 505957592@qq.com service agencies, undergraduate employment service agencies, social undergraduate employment intermediary organizations, and various social strengths. All these provide both public and operational services. This system is not only conducive to transferring a large proportion of undergraduate employment service function assumed by governments and schools into social organizations, but also could maximally reduce the government intervention actually operated in undergraduate employment social service system. It perfects deficiencies of governments and schools, gives full play to effects of social employment service organizations, and thus improves the operation quality and efficiency of undergraduate employment service system. As thus, the undergraduate employment service system can accord with contemporary requirements of society informatization, economic globalization and undergraduate employment marketization in service objects, service contents, service methods, assessment supervision, organization and coordination, and with real national conditions of China's social and economic transformation. However, multi-composing elements and wide service range in undergraduate employment social service system have inevitably led to some trade-off phenomena. It has posed threats to the vested benefits of each department and generated conflicts, so resultant forces cannot be formed. Thus, constructing scientific and reasonable multi-objective utility model for undergraduate employment social service system is essential.

The earliest multi-objective decision model constructed by a western economist called V. Pareto is usually applied to the decision with mutual contradiction and competition among multi-objectives. Assume that there are $n$ objectives in the decision process, and $p_{n}$ is the size to achieve the $i(i=1,2, \cdots, n)$ objective, then the multi-objective expectancy utility can be expressed by using the following function: 
$\max E\left\{U\left(p_{1}, p_{2}, \cdots, p_{n}\right)\right\}$.

Keeney (1974) pointed out that if each objective is mutually independent, then the utility could be added together. Assume that each decision objective of undergraduate employment service system satisfies independence conditions, it is the multi-objective expectancy utility that can be expressed as:

$$
U\left(p_{1}, p_{2}, \cdots, p_{n}\right)=f\left\{h_{1}\left(p_{1}\right), h_{2}\left(p_{2}\right), \cdots h_{n}\left(p_{n}\right)\right\}
$$

Under the precondition of $\sum_{i=1}^{n} \omega_{i}=1$, then

$U\left(p_{1}, p_{2}, \cdots, p_{n}\right)=\sum_{i=1}^{n} w_{i} h_{i}\left(p_{i}\right)$.

Considering the status quo of Chinese undergraduate employment, we can conclude four objectives that the undergraduate employment social service system should pursue: maximized network organization, lowest degree of risk, highest collaboration degree, and minimized operation cost. The maximized network organization represents the objective of "to cover all college students", highest collaboration degree represents the objective of "to improve quality and efficiency", while lowest degree of risk and minimized operation cost represents scientific development and reasonable feasibility of the undergraduate employment social service system. The following function of multi-objective utility model for undergraduate employment social service system on the foregoing facts is obtained as follows:

$\max U+w_{1} h_{1}\left(p_{1}\right)+w_{2} h_{2}\left(p_{2}\right)-w_{3} h_{3}\left(p_{3}\right)-w_{4} h_{4}\left(p_{4}\right)$

\section{GAME BETWEEN OPERATIONAL SERVICE AND PUBLIC SERVICE IN UNDERGRADUATE EM- PLOYMENT SOCIAL SERVICE SYSTEM}

In a perfect state, the undergraduate employment social service system shall be perceived as below. Operational service is assumed by intermediary organizations for social undergraduate employment or enterprise powers, and the public service is provided by undergraduate employment service agencies. Therefore, it is of crucial significance to master multi-objective utility model stated above and delve into game states of various behavior subjects when pursuing such a model. The decision-making subjects in public and operational services are governments and undergraduate employment service agencies, and intermediary organizations for the social college student employment. Assume both of them are "economic person" under a perfect state, then governments and undergraduate employment service agencies could pursue to maximize the social benefits, and intermediary organizations for the social college student employment pursue to maximize self-benefits based on the job market needs and their own preferences. We hold that, there are two attitude strategies governments and undergraduate employment service agencies can take for socialized service system for university student employment during the game process, that is to leading or not to leading process. While the strategy selection of the intermediary organizations for social undergraduate employment may be determined by whether to participate in socialized service system for undergraduate employment in consideration of job market needs and costs.

In this game model, assume that the profits earned by intermediary organizations for social undergraduate employment are solely sourced from the service area, and resource using tax $\mathrm{R}$ shall be paid in operation process of undergraduate employment service. At the same time, if they fail to participate in undergraduate employment service, service charge $a_{1} T$ shall be levied by the country, accordingly. If they choose to take part in social undergraduate employment service system, the service charge $a_{2} T$ shall be levied by the country. The fixed charge made from the leading process of governments and undergraduate employment service agencies is $\mathrm{G}$. If the undergraduate employment service agencies fail to participate in the undergraduate employment service system, the undergraduate employment service cost paid by the national finance shall be $b_{1} C_{1}$, accordingly; if they choose to participate in the undergraduate employment service system, the paid costs shall be $b_{2} C_{1}$, where the relation of $b_{1}>b_{2}$ is apparent. Intermediary organizations for undergraduate employment can maximize their own utilities by participating in operational services. Assume that they shall pay relevant costs $C_{2}$ for participating in undergraduate employment service system, profits $\mathrm{P}$ would also be obtained due to the effective job market needs in the meantime.

The payoff matrix of the governments and undergraduate employment service agencies, and intermediary organizations for social undergraduate employment in undergraduate employment service system can be obtained, as shown below (refer to Table 1):

Table 1. Payoff matrix of government and college student employment service organizations and social intermediary organizations for college student employment.

\begin{tabular}{|c|c|c|}
\hline $\begin{array}{r}\text { Government and College Student } \\
\text { Employment Service Organizations }\end{array}$ & Dominant & Non-dominant \\
$\begin{array}{l}\text { Social Intermediary Organizations } \\
\text { for College Student Employment }\end{array}$ & $P-a_{2} T-R-C_{2}, R+a_{2} T-G-b_{2} C_{1}$ & $P-R-C_{2}, R-b_{2} C_{1}$ \\
\hline \hline Participate & $-a_{1} T-R, R+a_{1} T-G-b_{1} C_{1}$ & $-R, R-b_{1} C_{1}$ \\
\hline Not Participate & & \\
\hline
\end{tabular}


Assume that probability for participation of social intermediary organizations for college student employment into socialized undergraduate employment service system is $p_{1}$, probability of non-participation is $1-p_{1}$; probability of dominance of government and college student employment service organizations is $p_{2}$; probability of non-dominance is $1-p_{2}$.

Income returns of social intermediary organizations for college student employment whether participating or not participating in socialized undergraduate employment service system, are respectively:

Income returns after participating:

Income return

$=p_{2} \times\left(P-a_{2} T-R-C_{2}\right)+\left(1-p_{2}\right) \times\left(P-R-C_{2}\right)$

Income returns after not participating:

$$
\text { Income return }_{2}=p_{2} \times\left(-a_{1} T-R\right)+\left(1-p_{2}\right) \times(-R)
$$

For government and college student employment service organizations, when benefits of social intermediary organizations for college student employment have game equilibrium after participating in socialized undergraduate employment service system, dominance probability of government and college student employment service organizations is optimal, i.e. Income return $1=$ Income return $_{2}$, then

$p_{2}=\frac{C_{2}-P}{T\left(a_{1}-a_{2}\right)}$

The above equation shows that there is preference for participation of government and college student employment service organizations into socialized undergraduate employment service system, it can be easily known that $a_{1}>a_{2}$.

Income returns under dominance and non-dominance strategy of government and college student employment service organizations are respectively:

Income returns under dominance:

$$
\begin{aligned}
\text { Income return }_{3}= & p_{1} \times\left(R+a_{2} T-G-b_{2} C_{1}\right) \\
& +\left(1-p_{1}\right) \times\left(R+a_{1} T-G-b_{1} C_{1}\right)
\end{aligned}
$$

Income returns under non-dominance:

Income return $4=p_{1} \times\left(R-b_{2} C_{1}\right)+\left(1-p_{1}\right) \times\left(R-b_{1} C_{1}\right)$

For social intermediary organizations for college student employment, if income return is the same whether government and college student employment service organizations are dominant or not dominant, optimal probability is obtained when social intermediary organizations for college student employment participate in socialized undergraduate employment service system and have game equilibrium in government and college student employment service organizations, i.e. Income return $3=$ Income return $_{4}$ and it can be easily obtained that

$p_{1}=\frac{a_{1} T-G}{T\left(a_{1}-a_{2}\right)}$.
To sum up, Nash equilibrium of the game strategy is

$$
\left(\frac{a_{1} T-G}{T\left(a_{1}-a_{2}\right)}, \frac{C_{2}-P}{T\left(a_{1}-a_{2}\right)}\right) .
$$

\section{RESULTS AND ANALYSIS}

(1) If social intermediary organizations for college student employment don't participate into socialized undergraduate employment service system, then the socialized service cost for college student employment in national finance is $b_{1} C_{1}$; if social intermediary organizations for college student employment participate into socialized undergraduate employment service system, then socialized service cost for college student employment in national finance is $b_{2} C_{1}$. Nash equilibrium of game shows irrelevance with $C_{1}, b_{1} b_{2}$. That is to say, whether government and college student employment service organizations are dominant in socialized undergraduate employment service system is not determined by whether social intermediary organizations for college student employment participate into socialized undergraduate employment service system. Under the current mechanism, government and college student employment service organizations should provide and dominate public benefit service. Also, responsibilities of public benefit service providers should be clarified, so that they could take establishing service-oriented organizations as the goal, avoid scrambling for interests or buck-passing or disputing over trifles, etc., play a leading role in the implementation of public benefit service and also demonstrate the country's confidence in maintaining college students' employment interests.

(2) The optimal probability under dominance of government and college student employment service organizations is

$$
\frac{C_{2}-P}{T-\left(a_{1}-a_{2}\right)} \text {. }
$$

It can be known from specific analysis that: first, the bigger the balance of service fee levied by the state is, the smaller the probability of dominance of government and college student employment service organizations is; the smaller the balance is, the bigger the probability of dominance of government and college student employment service organizations is. Ideally, operation of socialized undergraduate employment service system doesn't need dominance and intervention of government and college student employment service organizations. Socialized undergraduate employment service system under guidance of scientific concept of development should be a result of free game of employment market needs for socialized undergraduate employment service. In theory, infinite enlargement of leading role of government and college student employment service organizations is more reflected in the formulation of corresponding laws, regulations and policies to ensure sound operation of labor market. Second, on the assumption that charge for socialized undergraduate employment service is relatively 
standardized, when $C_{2}>P$, then cost for social intermediary organizations for college student employment to participate in socialized undergraduate employment service system is higher than the profit, so government and college student employment service organizations should promptly play a leading role, to stabilize market operation and ensure interests of social intermediary organizations for college student employment; otherwise, social intermediary organizations for college student employment will lose power, and aftereffect caused by such phenomenon as rising cost and relation of benefit deviation will be incalculable. Finally, government and college student employment service organizations should give play to the guiding role of finance, guide social intermediary organizations for college student employment in building multi-agent operation system, while providing financial subsidies, loan with discounted interest and other preferential policies, gradually form development mechanism according to which government indirectly guides, social intermediary organizations for college student employment are directly involved and market enjoys efficient operation. Also profit should be inclined to social intermediary organizations for college student employment or social forces which assume part of public benefit service and ensure their interests.

(3) The optimal probability for social intermediary organizations for college student employment to participate in socialized undergraduate employment service system is

$$
\frac{a_{1} T-G}{T-\left(a_{1}-a_{2}\right)} \text {. }
$$

Thus according to the conclusion the state should levy more socialized service fees. In addition, the balance between socialized service fee levied by the state and fixed cost during dominance of government and college student employment service organizations should be considered. The indicator requires that government and college student employment service organizations play a leading role during participation process. When fixed cost $G$ tends to be constant, probability is

$$
p_{1}=\frac{a_{1} T-G}{T\left(a_{1}-a_{2}\right)}=\frac{a_{1} T^{\prime}}{T\left(a_{1}-a_{2}\right)}=\frac{T^{\prime}}{T} \cdot \frac{1}{1-a_{2} / a_{1}}
$$

and ratio $a_{2} / a_{1}$ of socialized service charge factor $a$ is smaller. Under dominance of government and college student employment service organizations, game strategy probability for social intermediary organizations for college student employment to participate in socialized undergraduate employment service system depends on $T^{/} / T$, whereas $T^{\prime}$ relates to $a_{1}$. Then the final conclusion depends on factor of socialized service fee levied by the state, that is, tax incentives and financial subsidies should be reflected in participation of social intermediary organizations for college student employment in socialized undergraduate employment service system.

(4) Game result shows that from long-term perspective, social intermediary organizations for college student employment have certain advantages in construction of socialized undergraduate employment service system. In the process of achieving balance between social benefits and enterprises' own benefits, government should improve relevant laws and regulations, build a strong market supervision management mechanism. Meanwhile, social intermediary organizations for college student employment must abandon the principle of maximizing their own interests, to achieve sharing contract mechanism of multi-agent income. While government role gradually shifts in game model, more social functions will be undertaken by such participants as social intermediary organizations for college student employment which will also share more interests and enjoy more preferential policies. In addition, marginal utility of business services and public benefit service should be well dealt with. Various participants should share information and resources during actual execution of services, collaborate, actively communicate, avoid conflict and resource waste and reduce service costs as far as possible.

\section{STRATEGY FOR ESTABLISHING THE SOCIAL- IZED UNDERGRADUATE EMPLOYMENT SERVICE SYSTEM}

\subsection{Deepening Socialization Concept of Undergraduate Employment Service System}

In order to further enhance the socialization concept of under- graduate employment service system, we need to keep up with time pace, and take full consideration on China's practical national conditions. Therefore, we need to deepen the involvement of various social forces in understanding the socialization theory of undergraduate employment service system. In addition, we will take the initiative to adopt the change of employment market requirement, focus on the people-oriented concept, improve the efficiency and quality of the employment service, and expand undergraduate employment service space. Moreover, efforts should be laid to adopt the changing employment market requirement, to collect various employment information on the market, to specifically analyze the changing trend of employment requirement, to adjust the focuses, directions and patterns of undergraduate employment, and to timely release the employment information to undergraduates. Peopleoriented principle proposes the requirement that we should take the initiative to provide excellent employment service for college students based on their basic benefits. To improve the efficiency and quality of employment service, we need to not only increase the undergraduate employment rate, but also improve the employment quality. In order to expand the undergraduate employment service space, we need to coordinate various service resources for undergraduate employment and implement employment service purposely in a planned way based on the existing service structure. In addition, we should timely adjust employment service according to the different employment needs of college students, increasing the employment service efficiency, and developing an effective communication between service objects and servers.

\subsection{Scientific Positioning of the Role of Government}

Government should fully know the function and role itself, and understand what kind of the role it should take in serving undergraduate employment. Government should 
transform its function to some degree by preferring service functions and innovating the service pattern. By taking a guiding role in undergraduate employment service, government should make good use of employment policies, encourage and guide college students to choose grass-root employment, protect the employment rights and interests of disadvantaged students, and encourage undergraduate entrepreneurship, realizing the diversification of under-graduate employment condition. In addition, government should organize the involvement of social forces in undergraduate employment service so as to provide college students with policy support, guide social forces to establish employment market for college students, and encourage social forces to provide all forms of employment support and guidance for college students so as to expand the employment approaches.

\subsection{Further Excavating Social Resources for Under- graduate Employment Service System}

Various social resources are the foundation for implementing undergraduate employment service. In order to better realize the socialization theory of undergraduate employment service system, we should mobilize the social resources of undergraduate employment service system to a larger degree, track all forms of resources for employment service in real-time, excavate the exploration potential of social resources, and build the database of social resources for undergraduate employment service, so as to provide better employment service for college students. The investigation of potential of social resources for employment service includes issues such as the professional structure of employment service objects, population and age distribution of employment service object, amount of research organizations for employment service, condition of scientific forces, staff composition and quality status of personnel departments of enterprises and public institutions, compositions and quality of various employment service institutions and organizations. We need to lay big effort to excavate the potential of social resources for undergraduate employment service market, which should be regarded as an important compositional content of undergraduate employment service system, so as to realize the comprehensive socialized services of undergraduate employment.

\subsection{Establishment of Social Networking System of Un- der-graduate Employment Service System}

Under the new era, the modern service industry calls for informatization development, while the undergraduate em- ployment service also craves for an informatization development. Therefore, we need to construct a related socialized network for employment service system. There are three points we need to focus on: the first point is to realize a coconstruction and sharing social networking system of undergraduate service system. Guided by the central government, and co-supported by all levels and forms of employment service institutions, such a social networking system of employment service system should be constructed; the second point is to construct an information management platform and system with scientific, reasonable and user-friendly characteristics, realizing the functions of type-in, inquiring and editing the statistics of various employment service inforesources; the third one is to consolidate the information infrastructure construction for social networking development of employment service system, build a website of undergraduate employment service and maintain it well. Through this website, we can provide all forms of employment service information such as employment policies and rules, recruitment information, employment situation, jobapplication training, and guidance to pioneering an enterprise, giving a full play to the employment service functions of the website.

\section{CONFLICT OF INTEREST}

The author confirms that this article content has no conflict of interest.

\section{ACKNOWLEDGEMENT}

\author{
Declared none.
}

\section{REFERENCES}

[1] Z. L. Liu, "Fractal theory and application in city size distribution", Information Technology Journals, vol. 12, no. 17, pp. 4158-4162, 2013.

[2] D. Zhao, Discussion of the socialization of undergraduate employment service system, Education and Vocation, no. 12, pp. 59-60, 2007

[3] M. H. Olya and H. Fazlollahtabar, "Finding shortest path in a combined exponential gamma normal probability distribution arc length", Advances in Industrial Engineering and Management, vol. 3, no. 4, pp. 35-44, 2014.

[4] C. H. Liao, Analysis of long-term mechanism of employment guidance and service system in regional colleges-based on the case of jiaying university, Journal of Jiamusi Education Institute, no. 6, 2012 . 